\title{
Influence of category, herd size, grazing and management on epidemiology of bovine viral diarrhoea in dairy herds
}

\author{
Tomislav Bedeković ${ }^{*}$, Nina Lemo ${ }^{1^{*}}$, Ljubo Barbić ${ }^{2}$ Željko Cvetnić ${ }^{1}$, Ivana Lojkić1 \\ Miroslav Benić ${ }^{1}$, Željko Čač ${ }^{1}$, Mirko Lojkić ${ }^{1}$, Josip Madić ${ }^{2}$ \\ ${ }^{1}$ Croatian Veterinary Institute, Zagreb, Croatia \\ ${ }^{2}$ University of Zagreb, Faculty of Veterinary Medicine, Zagreb, Croatia \\ *Both authors contributed equally to this work
}

Received August 6, 2012

Accepted February 19, 2013

\begin{abstract}
The aim of this study was to estimate the influence of category, herd size, common grazing and management as risk factors in maintaining bovine viral diarrhoea infection in dairy herds. A total of 987 sera samples obtained from 202 heifers, 653 cows and 132 calves from 103 herds in Croatia were examined by enzyme-linked immunosorbent assay. In order to establish the prevalence of persistently infected cattle, 35 herds were selected. Ear notch tissue samples from all animals in selected herds $(n=2284)$ were collected and analyzed by antigen enzyme-linked immunosorbent assay. The true prevalence of specific antibodies was $61.61 \%$ and the estimated prevalence of exposure to bovine viral diarrhoea virus at the herd level was $100 \%$. The prevalence of persistently infected animals was $0.53 \%$ and the prevalence of persistently infected herds was $20 \%$. The antibodies prevalence was higher in cows, in herds that use common pasture and in larger herds $(P<0.001)$. The prevalence of persistently infected animals was not connected with the herd size but production management on big farms contributed to maintaining the virus. The obtained results suggest that production management was an important risk factor in bovine viral diarrohea epidemiology. High prevalence of antibodies and high prevalence of persistently infected herds requires implementation of control and eradication programs at a national or even regional level. The presented data complete the BVD epidemiological investigations from this part of Europe.
\end{abstract}

$B V D V$, epidemiology, risk factors

Bovine viral diarrhoea virus (BVDV) belongs to the Pestivirus genus within the Flaviviridae family (Heinz et al. 2000). The Pestivirus genus consists of four closely related species: Bovine viral diarrhoea virus 1 (BVDV-1), Bovine viral diarrhoea virus 2 (BVDV-2), Classical swine fever virus (CSFV) and Border disease virus (BDV). Both BVDV species occur in cytopathic (cp) and non-cytopathic (ncp) forms according to whether or not it produces visible change in cell cultures. Bovine viral diarrhoea virus is a causative agent of disease in domestic and wild ruminants. Breeds of cattle do not have any influence on BVD infection (Brock at al. 2005). In contrast, the influence of herd size measured as the number of cows, mean distance to neighbouring herds, and sharing of common pasture are proven as important risks factors in BVD epidemiology (Valle et al. 1999; Alban et al. 2001).

Persistently infected (PI) cattle act as a viral reservoir and main factor of virus maintenance in the herds (Houe 1999). Infection with ncp biotypes in immunocompetent and seronegative cows or heifers in the first four months of pregnancy may lead to the birth of PI calves with no apparent clinical signs.

Some European countries conduct a national program for control and eradication of BVD. Before starting the program, in most European countries the disease was present in the endemic form with a prevalence of specific antibodies of $60-80 \%$, and with a prevalence of PI cattle of $0.5-2 \%$ (Lindberg et al. 2006; Robesova et al. 2009). In some countries (Norway), the program has been successfully completed, and in some countries it is in its final stage.

Address for correspondence:

Tomislav Bedeković

Croatian Veterinary Institute

Savska cesta 143, 10000 Zagreb, Croatia
Phone: $+385(0) 16123605$

Fax: $+385(0) 16123670$

E-mail: bedekovic@veinst.hr

http://actavet.vfu.cz/ 
Different diagnostic methods can be used for the diagnosis and monitoring. However, Enzyme-Linked Immunosorbent Assay (ELISA) and antigen ELISA are the best tools for screening because they are simple, inexpensive and fast methods with high sensitivity and specificity (Hill et al. 2007). The virus can be detected in almost all organs of PI animals (Houe 1999). The advantage of ear notch tissue samples is in easier sampling. Also, the presence of antibodies does not interfere with virus detection.

In Croatia, there is no national program for control and eradication of BVD, and vaccination is conducted just in some herds on voluntary basis. According to the latest survey, the prevalence of specific antibodies was 79.2\% (Biuk-Rudan et al. 1999). However, in that research only 124 cattle were tested in four herds.

The aim of this study was to estimate the influence of category, herd size, common grazing and production management as risk factors in maintaining BVD infection within dairy herds. Furthermore, this study should elucidate the role of BVD in dairy herds and provide information on the BVD situation in Croatia, and provide all necessary data as basis for the selection of control and eradication strategy.

\section{Materials and Methods}

\section{Study populations}

Stratified random sampling was used for selection of non-vaccinated dairy herds and animals in herds. Dairy herds were randomly selected based on the number of dairy herds from the Unique Register of domestic animals. At the end of 2008, 184692 dairy cattle and 22902 herds were recorded in the register; constituting $82.22 \%$ of all cattle population in Croatia. Animals used in this study were randomly selected based on the list of animals for each herd from the register using a computer generated list. Sample size required for estimation of prevalence of antibodies and prevalence of PI cattle were calculated using WIN Episcope version 2.0 (EPIDECON). According to this program we needed to test 103 herds if estimated antibody prevalence was $50 \%$ to accomplish confidence of $95 \%$ within $10 \%$. For PI cattle prevalence, according to the same program we needed to test 35 herds if estimated prevalence of PI cattle was $10 \%$ to accomplish confidence of $95 \%$ within $10 \%$. Furthermore, to establish antibody prevalence with the estimated prevalence of $50 \%$ we needed to test at least four animals within a herd to detect at least one positive animal. For PI animal detection in herds with the estimated prevalence of $0.5 \%$ we needed to test all animals to accomplish detection of at least one positive animal.

Depending on sizes, herds were classified into four categories: I - herds with up to 20 animals, II - herds with 21-50 animals, III - herds with 51-100 animals and IV - herds with 101 and more animals. For antibody prevalence study, 103 herds were selected including herds that use common pastures. The sizes of selected herds were as follows: 36 herds with up to 20 animals, 25 herds with $21-50$ animals, 30 herds with 51-100 animals, 12 herds with 101 and more animals. The samples were collected from the whole counties except for the Dubrovnik County.

For PI cattle prevalence, 35 herds were selected. The sizes of selected herds were as follows: 13 herds with up to 20 animals, 7 herds with 21-50 animals, 9 herds with 51-100 animals, 6 herds with 101 and more animals. All samples for PI cattle prevalence study $(n=2284)$ originated from herds that do not use common pastures.

\footnotetext{
Sampling

Sera samples were obtained from 202 heifers, 653 cows and 132 calves within 103 herds between January 2009 and January 2010. Blood samples were collected from the tail vein into Vacutaineir systems. At least $5 \mathrm{ml}$ per animal was collected. Blood samples were centrifuged for $10 \mathrm{~min}$ at $200 \times \mathrm{g}$. Sera were placed into sterile tubes and stored at $-20^{\circ} \mathrm{C}$ until testing. The minimum number of collected sera per herd was 9 and the maximum was 11. At the same time the blood samples were collected, data on the category, herd size and data considering the use of common pasture were collected. During sampling for PI prevalence, descriptive data on the organisation of production (management) on farms were collected.

Ear notch tissue samples $(\mathrm{n}=2284)$ for virus prevalence study were collected using piglet ear-notching pliers.
}

\section{Serology}

The test to detect BVDV antibodies was performed using a commercially available kit according to manufacturer's instructions, in which wells were coated with BVDV antigen (Herdchek BVDV, IDEXX, Liebefeld-Bern, Switzerland). The true antibody prevalence at individual level was calculated from apparent according to following formula: (apparent prevalence + Ag ELISA specificity - 1) / (Ag ELISA sensitivity + Ag ELISA specificity - 1).

Persistent infection

For detection of persistently infected animals, viral antigen was detected in ear notch tissue using a commercially available kit according to manufacturer's instructions, in which wells are coated with BVDV E ${ }^{\text {rns }}$ antibody (Herdchek BVDV Ag/Serum Plus, IDEXX, Liebefeld-Bern, Switzerland). From all virus positive cattle 
at initial sampling, ear notch tissue sampling was repeated after 4 weeks. Persistent infection was confirmed with repeated positive results 4 weeks after first testing.

Data analysis

For statistical analysis, Stata 10 (Statacorp, Texas, USA) program was used. Prevalence of specific antibodies among different categories and herds of different sizes were compared using Chi square test. Using the same test antibodies, prevalence was compared between herds that do not use common pastures and herds that use common pastures. Association of PI animal prevalence with herd size was checked using Fischer exact test. Odds ratios regarding the association of antibody prevalence with use of common pastures was calculated using logistic regression. $P$ value of $<0.05$ was considered significant.

\section{Results}

Antibody prevalence

Apparent prevalence of specific antibodies in cattle was 59.57\% (588/987); the true antibody prevalence was $61.61 \%$. At the herd level, the estimated antibody prevalence was $100 \%$. The results of prevalence of specific BVD antibodies with regard to age category, herd size and grazing are summarized in Table 1. The observed difference of antibody prevalence between age categories was significant $(P<0.001)$ with the highest prevalence in cows. Antibody prevalence between herds of different sizes was significant $(P<0.0001)$ and increased proportionally with herd size. Furthermore, the prevalence of BVD antibodies was significantly different in herds that use common pastures compared to herds that do not $(P<0.001)$. The frequency of BVD antibodies in herds that used common pasture was more than $7 \times$ higher compared to herds that do not use common pastures (OR $=7.2 ; 95 \%$ CI 3.6-14.6).

Table 1. Seroprevalence of specific bovine viral diarrhoea virus antibodies in cattle with regard to category, herd size and grazing.

\begin{tabular}{llcr}
\hline & & $\mathrm{n}$ & Positive (\%) \\
\hline Categories & heifers & 202 & $71(35.2)$ \\
& cows & 653 & $446(68.3)$ \\
\multirow{4}{*}{ Herd size } & calves & 132 & $71(53.8)$ \\
& $<20$ & 339 & $133(39.2)$ \\
& $20-50$ & 236 & $121(51.3)$ \\
\multirow{3}{*}{ Grazing } & $50-100$ & 294 & $222(75.5)$ \\
& $>100$ & 118 & $112(94.9)$ \\
& without common pastures & 896 & $506(56.5)$ \\
& on common pastures & 91 & $82(90.1)$ \\
\hline
\end{tabular}

\section{Persistently infected cattle prevalence}

Ear notch tissue samples were obtained from 2284 cattle of 35 herds. Persistent infection was detected in $12(0.53 \%)$ animals ( 5 cows, 2 pregnant heifers, 5 heifers) in 7 herds (Table 2 ). At the herd level, the prevalence was $20 \%$. Prevalence of PI cattle was not associated with herd size $(P<0.9)$.

\section{Management data}

In all herds with up to 50 animals (except for one), cattle of all categories were placed together in one stable. In that one exception, herd heifers were placed in a separate stable before they became pregnant. In the herd where heifers were placed in a separate stable, persistently infected cattle was detected. In herds with 51 and more animals, heifers were placed separately from other categories before they became pregnant. 
Table 2. Seroprevalence of persistently infected cattle with regard to category and herd size.

\begin{tabular}{llcc}
\hline & & $\mathrm{n}$ & Positive (\%) \\
\hline Categories & heifers & 375 & $7(1.9)$ \\
& cows & 1674 & $5(0.3)$ \\
& calves & 235 & $0(0)$ \\
\hline Herd size & $<20$ & 210 & $0(0)$ \\
& $20-50$ & 226 & $1(0.4)$ \\
& $50-100$ & 618 & $5(0.8)$ \\
& $>100$ & 1220 & $6(0.5)$ \\
\hline Total & & 2274 & $12(0.5)$ \\
\hline
\end{tabular}

\section{Discussion}

Until this study the impact of BVD in Croatia has never been investigated at a national level. According to this study, prevalence of BVDV antibodies in dairy herds was $61.6 \%$. These data are in accordance with the data for the prevalence of $60-80 \%$ in most European countries (Lindberg et al. 2006). The highest prevalence was recorded in cows, followed by calves and heifers. Cows stay longer in herds compared to calves and heifers; therefore there bigger probability for them to become infected. Higher antibody prevalence in calves compared to heifers can be explained with colostrum antibodies. The lowest prevalence was recorded in heifers. This can be explained by the fact that in most cases on big farms heifers were placed separately until they became pregnant.

Although the prevalence of BVD antibodies at national level in Croatia is not extremely high, it is important that the estimated prevalence among herds with 100 and more cattle is $94.9 \%$. Also, according to this study antibody prevalence is connected with the herd size. Large herds with 100 and more animals are the main source of milk production in Croatia and obviously the impact of BVD on those herds is enormous.

The prevalence of specific antibodies in herds with up to 50 animals that use common pastures was almost similar to herds with 100 and more animals that do not use common pastures. This result supports the finding that common pastures are a risk factor in BVD epidemiology (Valle et al. 1999).

On herd level, the estimated prevalence of antibodies was $100 \%$. That means that each of the tested herds had at least one positive animal. However, in some herds the prevalence was low. The lowest antibody prevalence was observed among herds with 20 or less animals. This observation can explain previous computer modelling estimations that infection is contained earlier in smaller herds compared to larger herds (Smith et al. 2010).

The prevalence of PI animals and PI herds was $0.53 \%$ and $20 \%$, respectively. These findings were in accordance with similar data from other countries (Rüfenacht et al. 2000).

The prevalence of PI herds was slightly below of the prevalence found in other European countries (Houe and Meyling 1991; Frey et al. 1996; Schreiber et al. 1999). These findings can be explained by the large number of herds with 20 or less animals in Croatia. Although the connection between frequency of virus prevalence and herd size in our study was not significant, 11 PI cattle of the 12 detected was found in six herds with more then 50 animals per herd. One of the reasons for that can be in different management techniques on small farms compared to large farms. Female calves on big farms were separated from the herds early after birth. Calves stay separately until they reach sexual maturity. After artificial insemination heifers are placed back into the 
herd. For these reasons, heifers are seronegative. When heifers come infected with the virus during the second trimester of pregnancy, the virus can infect the foetus and cause persistent infection.

In each of the PI herds, PI cows or PI pregnant heifers were confirmed but not PI calves. Those findings are in conflict with the general presumption that PI animals commonly do not live long enough to reach reproductive maturity (Duffel and Harkness 1985). The reason that persistent infection has not been detected in calves can be just coincidence or such calves had been excluded from the herd because of growth retardation.

All positive animals were detected in the central, northern and eastern parts of Croatia. In those regions, the density of cattle population is high and these data support previous findings (Lindberg 2006).

In conclusion, BVD is present in Croatia in endemic form with seroprevalence of $61.61 \%$ and with PI animals prevalence of $0.53 \%$. The finding of almost $95 \%$ antibody positive cattle in herds with 100 animals and more implies a major impact of BVD on dairy herds and milk production in Croatia. According to this study the main risk factor for the maintenance of the virus within herds is keeping heifers separately from the rest of the herd before they become pregnant. The obtained results suggest that changes in management may lead to the break of the chain of infection, and potentially to elimination of PI animals. Such changes in management can positively influence the results of control and eradication programs at national or even regional level.

\section{Acknowledgments}

This research was supported by grant No. 048-0481186-1183 of the Ministry of Science, Education and Sports, Republic of Croatia.

\section{References}

Alban L, Stryhn H, Kjeldsen AM, Ersbøll AK, Skjøth F, Christensen J, Bitsch V, Chriél M, Strøger U 2001: Estimating transfer of bovine virus-diarrhoea virus in Danish cattle by use of register data. Prev Vet Med 52: 133-146

Biuk-Rudan N, Cvetnić S, Madić J, Rudan D 1999: Prevalence of antibodies to IBR and BVDV viruses in dairy cows with reproductive disorders. Theriogenology 51: 875-881

Brock KV, Grooms DL, Givens MD 2005: Reproductive disease and persistent infection, 145-156. In: Goyal SM, Ridpath JF (eds.): Bovine viral diarrhea virus. Diagnosis, management, and control. $1^{\text {rst }}$ Ed. Blackwell Publishing. Ames, Iowa, $261 \mathrm{p}$.

Duffel SJ, Harkness J W 1985: Bovine virus diarrhea-mucosal disease infection in cattle. Vet Rec 117: 240-245

Frey HR, Flebbe U, Lies B 1996: Prevalenz und klinische Sympomatik persistenter BVD-virusinfektionen in Rinderbestanden Niedersachsens. (Prevalence and clinical symptoms of persistent BVD virus infections in cattle herds in Lower Saxony). Der praktische Tierarzt (in German) 77: 49-52

Heinz FX, Collett MS, Purcell RH, Gould EA, Howard CR, Houghton M, Moormann RJM, Rice CM, Thiel HJ 2000: Family Flaviviridae. In: Van Regenmortel MHV, Fauquer CM, Bishop DHL, Carstens E, Estes MK, Lemon S, Maniloff J, Mayo MA, McGeogch D, Pringle CR, Wickner RB (eds.): Virus Taxonomy, $7^{\text {th }}$ International committee for the Taxonomy of Viruses. Academic Press. San Diego, $1162 \mathrm{p}$.

Hill FI, Reichel MP, McCoy RJ, Tisdall DJ 2007: Evaluation of two commercial enzyme-linked immunosorbent assays for detection of bovine viral diarrhoea virus in serum and skin biopsies of cattle. New Zeal Vet J 55: 45-48

Houe H 1999: Epidemiological features and economical importance of bovine viral diarrhoea virus (BVDV) infections. Vet Microbiol 64: 89-107

Houe H, Meyling A 1991: Prevalence of bovine viral diarrhea (BVD) in 19 Danish dairy herds and estimation of incidence of infection in early pregnancy. Prev Vet Med 11: 9-16

Lindberg A, Brownlie J, Gunn GJ, Houe H, Moennig V, Saatkamp HW, Sandvik T, Valle PS 2006: The control of bovine viral diarrhoea virus in Europe: today and in the future. Rev Sci Tech (OIE) 25: 961-979

Robesova B, Kovarcik K, Vilcek S 2009: Genotyping of bovine viral diarrhea virus isolates from the Czech Republic. Vet Med 54: 393-398

Rüfenacht J, Schaller P, Audigé L, Strasser M, Peterhans E 2000: Prevalence of cattle infected with bovine viral diarrhoea virus in Switzerland. Vet Rec 147: 413-417 
Schreiber P, Dubois F, Dreze G 1999: Prevalence of bovine virus diarrhoea virus infection in Belgian White Blue cattle in southern Belgium. Vet Quart 21: 28-32

Smith RL, Sanderson M W, Renter DG, Larson R, White B 2010: A stochastic risk-analysis model for the spread of bovine viral diarrhea virus after introduction to naïve cow-calf herds. Prev Vet Med 95: 86-98

Valle PS, Martin SW, Tremblay R, Bateman K 1999: Factors associated with being a bovine-virus diarrhea (BVD) seropositive herd in the More and Romsdal county of Norweay. Prev Vet Med 40: 165-177 